\title{
Acute effect of intra-set static stretching on antagonists versus passive interval on the performance of maximum repetitions of agonists in leg extension machine
}

\section{Efeito agudo do alongamento estático intra-séries nos antagonistas versus intervalo passivo sobre 0 desempenho de repetições máximas dos agonistas na cadeira extensora}

\section{Priscila Alves de Souza ${ }^{1}$ \\ (D) https://orcid.org/0000-0001-6345-3531 \\ Diego Rodrigues Teixeira ${ }^{1}$ \\ (D) https://orcid.org/0000-0001-5913-2276 \\ Jaime Della Corte ${ }^{1}$ \\ (iD) https://orcid.org/0000-0003-2623-4684 \\ Camila Aparecida de Souza Batista ${ }^{1}$ \\ (D) https://orcid.org/0000-0002-3603-3416 \\ Humberto Lameira Miranda \\ (D) https://orcid.org/0000-0003-2129-3546 \\ Gabriel Andrade Paz' \\ (D) https://orcid.org/0000-0001-8474-9753}

Abstract - The aim of this study was to investigate the acute effect of intra-set antagonist static stretching (hamstrings) on the performance of maximum repetitions of knee extensors adopting muscle endurance training zone. The sample consisted of 15 healthy male volunteers with experience in strength training $(23.7 \pm 4.3$ years, $81.9 \pm 15.0 \mathrm{~kg}, 1.8 \pm 0.1 \mathrm{~m})$. Two experimental protocols were conducted: protocol without static stretching (PT) and antagonist stretching protocol (PAA) in the knee extension exercise. The results showed that there was no difference between protocols or interactions between protocols and sets in maximum repetitions performance (PT, set $1-21.3 \pm 3.4$; set $2-16.1 \pm 1.9$; set $3-13.5 \pm 1.3$ / PAA, set $1-21.0$ \pm 2.0 ; set $2-16.7 \pm 2.6$; set $3-13.7 \pm 2.2)(p \leq 0.05)(p \leq 0.05)$. Therefore, antagonist static stretching does not influence performance of maximum repetitions of knee extensors over multiple sets focused on muscle endurance.

Key words: Exercise; Quadriceps; Stretching; Strength.

Resumo - O objetivo do presente estudo é investigar o efeito agudo do alongamento estático (AE) dos músculos antagonistas (isquiostibiais) intra-série no volume de repetiçôes máximas dos extensores de joelho no exercicio cadeira extensora. A amostra foi composta por 15 homens voluntários, saudáveis, com experiência em treinamento de força $(23,7 \pm 4,3$ anos, $81,9 \pm 15,0 \mathrm{~kg}, 1,8 \pm 0,1 \mathrm{~m})$. Foram realizados dois protocolos experimentais, protocolo sem alongamento estático prévio (PT) e protocolo de alongamento dos antagonistas (PAA). Os resultados demonstraram que não houve diferença entre os protocolos ou interaçôes entre protocolos e séries no desempenho de repetições máximas $(p \leq 0,05)$. Não havendo também decréscimos no desempen ho de força muscular. Conclui-se que é provável que o AE não influencie um maior desempen ho de repetiçôes máximas quando aplicado em faixa de repetições voltadas à resistência muscular.

Palavras-chave: Alongamento; Exercício; Força; Quadriceps.
1 Federal University of Rio de Janeiro. School of Physical Education and Sports. Rio de Janeiro, RJ. Brazil.

Received: November 14, 2018 Accepted: August 30, 2019

How to cite this article Souza PA, Teixeira DR, Della Corte J, Batista CAS, Miranda HL, Paz GA. Acute effect of intra-set static stretching on antagonists versus passive interval on the performance of maximum repetitions of agonists in leg extension machine. Rev Bras Cineantropom Desempenho Hum 2020, 22:e60225. DOI: http://dx.doi.org/10.1590/19800037.2020v22e60225

Copyright: This work is licensed under a Creative Commons Attribution 4.0 International License. 


\section{INTRODUCTION}

Flexibility is considered a physical valence that can provide numerous beneficial health effects, such as improved functional capacity in daily activities, maintenance and gain of joint amplitude, as well as improvements in postural stability and balance ${ }^{1}$. According to Coelho ${ }^{2}$, flexibility is related to the viscoelastic properties of muscles, ligaments, and other connective tissues, which will provide movement of one or more joints through range of motion.

Scientific literature presents three types of stretching methods most commonly used: static, ballistic and proprioceptive neuromuscular facilitation $^{3-5}$. Static stretching (SS) is considered efficient to produce acute increase in range of motion ${ }^{6,7}$. However, there are studies pointing out that strength and power deficit and maximum force production capacity are dependent on the stretching volume. High stretching volumes, such as approximately 360 seconds, are sufficient to influence this deficit ${ }^{8-10}$. However, when performed at submaximal intensity and low volume, they may not compromise strength and power performance ${ }^{11-13}$.

According to previous studies, the application of SS before exercise has been questioned. Some evidence suggests that SS is unlikely to prevent injuries $^{14}$. On the other hand, several studies indicate that pre-exercise SS can significantly reduce performance in muscle strength tests ${ }^{15-17}$. Other studies have found that muscle stretching do not reduce muscle strength performance ${ }^{18}$.

Paz et al. ${ }^{3}$ conducted a study with sixteen young women with previous experience in strength training applying the proprioceptive neuromuscular facilitation $(\mathrm{PNF})$ technique to the antagonist muscles before a set of 10 maximum repetition loads in sitting open rowing exercise and observed a significant increase in the number of repetitions performed and in the electromyographic signal (EMG) of agonist muscles (latissimus dorsi and biceps brachii), compared to protocol without antagonist pre-activation via PNF stretching. As in the study by Miranda et al. ${ }^{19}$, conducted with eleven recreationally trained individuals, who performed knee flexion and biceps curl exercises, a significant improvement in the muscle performance of agonists with increased maximum repetitions after static stretching of antagonist muscles in both protocols.

In a study by Miranda et al. ${ }^{20}$ performed with ten recreationally trained subjects with previous experience in strength training, the effects of passive static stretching of 40 seconds of the pectoralis major muscle, antagonist in the sitting row exercise were verified. During the interval between sets in the performance of seated row repetitions, the results demonstrated significant improvement in the volume of maximal repetitions completed after SS of antagonist muscles.

There is little evidence associated with the application of static stretching to knee extensor (hamstring) antagonist muscles in the performance of maximal repetitions in the intra-set leg extension machine; however, the potential effects of applying muscle stretching of antagonists are not yet clear 
in literature ${ }^{21,22}$. Thus, scientific evidence related to the potential effects of antagonist pre-activation on muscle performance and muscle activation in dynamic actions under ecological conditions similar to the practical reality of strength training may assist professionals of training and rehabilitationrelated areas in prescribing and evaluating muscle performance by applying protocols involving reciprocal actions of agonists / antagonists.

Therefore, the aim of the present study was to investigate the acute effect of static stretching of the intra-set antagonist (hamstring) muscles versus passive recovery interval on the maximum repetition volume of knee extensors in the leg extension machine. One of the hypotheses considered is that there is an increase in the performance of repetition volume in the exercise prformed in the leg extension machine for agonist muscles (knee extensors) after the application of static stretching in antagonist muscles (knee flexors) compared to protocol without stretching.

\section{METHOD}

\section{Research Characterization}

This is an experimental crossover research ${ }^{23,24}$. This research model consists of an experiment conducted with randomly formed groups, with the objective of researching the response level due to specific manipulation in the dependent variables for a brief period of time.

\section{Sample}

The sample consisted of 15 male healthy volunteers with previous experience in strength training aged $23.7 \pm 4.3$ years. Inclusion criteria were: a) to practice strength training for at least one year; b) to have previous experience in the proposed exercise; c) to have no history of osteomioarticular injury; d) negative PAR-Q.

Exclusion criteria were: a) to exercise the muscle groups involved in the research exercise up to 48 hours before the experiment; b) to have performed flexibility training in these muscles up to 48 hours before data collection; c) individuals with joint limitations that may interfere with the proposed exercises.

\section{Research Ethics}

All individuals signed the free and informed consent form, according to National Health Council Resolution 466/2012, and were instructed on protocols, experimental risks and equipment used, and were instructed not to perform training $48 \mathrm{~h}$ before sessions. The research project was submitted to the Ethics Committee of Research Involving Human Beings of UFRJ and duly approved according to protocol: 08657113.0.0000.5257.

\section{Procedures}

On the first visit, the participant became familiar with test procedures. Familiarization was performed in the leg extension machine with a series 
of 12 repetitions and in the hip flexor stretching with knee extended with 30 seconds of passive static stretching for each limb. One day after familiarization, participants performed 20 maximum repetitions in the leg extension machine (20RM) to determine the maximum load. To confirm loads, 48 hours after the 20RM test, 20RM retest was performed. After determining the 20RM loads, the test protocols were randomly performed with minimum interval of $72 \mathrm{~h}$ between test protocols.

\section{RM test on the leg extension machine}

Individuals were submitted to load determination to the 20 maximum repetition test (20 RMs), that is, the highest weight obtained in both days (test and retest) was verified, with difference less than $5 \%$ between them. In the event of a larger difference, subjects would be asked to perform a new test so that this difference could be recalculated.

To minimize possible errors in the application of 20RMs tests, the following strategies were adopted: (a) all subjects received standardized instructions of the data evaluation routine and exercise technique to be applied before the test, (b) the technique of exercise during all test sessions was monitored and corrected as necessary and (c) all subjects received verbal encouragement during the test. During the 20RMs test, each subject performed a maximum of three exercise attempts with a 5-minute interval between attempts. Standard exercise techniques were followed. No pause was allowed between eccentric and concentric phases of one repetition or between repetitions. For a repetition to be successful, a full range of motion, as is usually defined by the exercise, would have to be completed.

\section{Exercise Standardization}

The knee extension exercise in the leg extension machine was described by Monteiro and Simão ${ }^{26}$ as follows: The initial position was made with individual in the sitting position, with arms along the body holding the support of the apparatus, with trunk inclination at $70^{\circ}$ and knee flexed at $90^{\circ}$ with head in the Frankfurt plane; and the development of the exercise was performed from the initial position, the full extension of legs was performed. After the end of extension, legs returned to the initial position.

\section{Traditional Protocol (PT)}

Initially, a specific warm-up of a set of 12 repetitions with $60 \%$ of the load was performed. After warm-up, 3 sets with 20-RMs load were performed until concentric failure with passive interval of 2 minutes between each set.

\section{Antagonist Stretching Protocol (PAA)}

In the protocol with antagonist stretching (PAA), specific warm-up of a set of 12 repetitions with $60 \%$ of the load was performed. After warm-up, 3 sets with $20 \mathrm{RMs}$ load were performed until concentric failure where stretching was performed immediately before and at intervals between sets. As antagonist stretching protocol, 2 sets of 30 seconds passive stretching 
were adopted for each limb with total duration of 2 minutes. The tension time in each set and protocol was recorded in the leg extension machine.

\section{Static Stretching}

Subjects were positioned in supine position and the evaluator passively performed hip flexion with knee extended, keeping the other lower limb resting on the ground ${ }^{27}$. According to $\mathrm{ACSM}^{1}$ recommendations, 10 to 30 seconds of tension is recommended, resulting in a total volume of 60 seconds for each muscle stretching exercise performed from 2 to 4 sets. Therefore, two sets of passive static stretching were used in this study, being unilaterally performed alternating sides without pauses between sets and sustaining the tension position for 30 seconds in each limb, resulting in a total time of two minutes.

\section{Statistical treatment}

Statistical treatment was performed using SPSS software version 20.0 (Chicago, IL, USA). Statistical analysis was initially performed using the Shapiro-Wilk normality test and homoscedasticity test (Bartlett criterion). All variables presented normal distribution and homoscedasticity. The intraclass correlation coefficient $(\mathrm{ICC}=(\mathrm{MSb}-\mathrm{MSw}) /[\mathrm{MSb}+(\mathrm{k}-1) \mathrm{MSw})$ was calculated to verify the reproducibility of test and retest of 20RM. Two-way repeated measures ANOVA $(2 \mathrm{x} 4)$ followed by Bonferroni post hoc was applied to determine whether significant difference or interaction occurred between type of training (traditional versus antagonist stretching) and between sets (1-4) in relation to the performance of maximum repetitions and time under tension. $\mathrm{P}$ value $\leq 0.05$ was adopted for all inferential analyses.

\section{RESULTS}

ICC for the 20RM test and retest in the leg extension machine was 0.94 . The sample characteristics can be observed in Table 1.

Table 1. Mean (standard deviation) of the sample characteristics

\begin{tabular}{ccccc}
\hline Age (years) & Body mass $(\mathrm{kg})$ & Height $(\mathrm{m})$ & BMI & 20-RM load $(\mathrm{kg})$ \\
\hline $23.7(4.3)$ & $81.9(15.0)$ & $1.8(0.1)$ & $26.1(3.8)$ & $73.7(16.2)$ \\
\hline
\end{tabular}

Note. BMI - Body Mass Index; RM - Maximum Repetition

Regarding performance of the maximum repetition (Table 2), there was no difference between protocols or interactions between protocols and sets $(p \leq 0.05)$. On the other hand, significant differences were observed between intra-protocol sets $(\mathrm{F}=75.342 ; \mathrm{p} 0.0001)$.

Regarding time under tension (Table 3), there was no difference between protocols or interactions between protocols and sets $(\mathrm{p} \leq 0.05)$. On the other hand, significant differences were observed between intraprotocol sets $(\mathrm{F}=42.359 ; \mathrm{p} 0.0001)$. 
Table 2. Mean (standard deviation) of the maximum repetition performance

\begin{tabular}{lccc}
\hline & Set 1 & Set 2 & Set 3 \\
\hline Traditional Protocol & $21.3(3.4)$ & $16.1(1.9)^{\star}$ & $13.5(1.3)^{\star} \dagger$ \\
Antagonist Stretching & $21.0(2.0)$ & $16.7(2.6)^{\star}$ & $13.7(2.2)^{*} \dagger$ \\
\hline
\end{tabular}

Table 3. Mean (standard deviation) of time under tension (seconds)

\begin{tabular}{lccc}
\hline & Set 1 & Set 2 & Set 3 \\
\hline Traditional Protocol & $26.7(5.3)$ & $20.1(3.3)^{*}$ & $17.4(2.8)^{*} \dagger$ \\
Antagonist Stretching & $25.5(5.3)$ & $20.6(3.6)^{*}$ & $16.3(1.8)^{*} \dagger$ \\
\hline
\end{tabular}

\section{DISCUSSION}

The results showed that in this study, there was no significant difference in the number of maximum repetitions between PT and PAA protocols. Thus, the initial hypothesis raised of a possible performance increase in the repetition volume in the leg extension machine exercise for agonists (knee extensors) after SS application in antagonist muscles (knee flexors) compared to PT protocol was not confirmed. However, it is important to observe that there was no deleterious effect of strength observed through the number of maximum repetitions in the present study, as observed in previous studies that demonstrated reduction in strength and muscle power after muscle stretching ${ }^{7-10}$.

Similar studies using antagonist stretching techniques have resulted in improved maximal repetition performance ${ }^{3,19,20,28}$. The results of the present study regarding the number of maximum repetitions did not corroborate the study by Miranda et al. ${ }^{19}$ who verified the acute effect of static stretching on antagonists on the maximal repetition test for agonist muscles of eleven individuals with previous experience in strength training. Two sets of 40 seconds of static stretching were performed on each limb of the following movements, knee flexion and shoulder abduction with flexing elbow. Immediately after stretching of knee extensors, leg extension exercise was performed, and immediately after stretching of biceps antagonists, biceps curl exercise was performed. There was significant increase in the number of maximal repetitions of agonists in the SS protocol compared to protocol without stretching in the leg extension and biceps curl exercises. Another study that investigated the effects of passive static stretching during interval between sets on the performance of repetitions and muscle activation in the sitting row exercise resulted in a 12 to $15 \%$ increase in the performance of maximum repetitions for the proposed exercise ${ }^{20}$.

In the study by Sandberg et al. ${ }^{4}$ conducted with sixteen trained men, three 30-second sets of SS of the hamstring muscle group were performed and isokinetic knee extension test was performed at two speeds, fast and slow; in addition, 3 series of 30 seconds of SS of hip flexors and dorsiflexors and the vertical jump test were performed. There was a considerable improvement in agonist performance in vertical jump and extensor isokinetic 
torque. According to the authors, some aspects such as accumulation of elastic energy and morphological alterations (reduction in the muscle spindle trigger point and relaxation in the activation of Golgi tendon organs) favored by the application of SS to the antagonists may be correlated to the results verified. However, the studies did not find significant differences in muscle activity through EMG signal, that is, the increase in maximal repetitions cannot be correlated with a possible reduction in SS-induced coactivation of antagonists ${ }^{4,20}$.

Robbins et al. ${ }^{21}$ conducted a study with sixteen trained men, and found no significant difference in the effect of antagonist pre-activation on longbar rowing exercise on agonist muscle power using bench press with $40 \%$ of $1 \mathrm{RM}$ compared to protocol without pre-activation, and the authors considered as one hypothesis the fact that pre-activation using 4-RM did not favor changes in the three-phase activation pattern (agonist-antagonistagonist), a fact that may have occurred in the present study due to the nonoccurrence of significant differences between protocols for the 20-RM load.

In this study, no significant differences in time under tension were observed between PT and PAA protocols, a result similar to that obtained by Santiago et al..$^{29}$, who verified the effect of SS on extensor and flexor muscles of the knee prior to exercise in the Leg Press.

Reduction in intra-protocol maximum repetitions was observed in this study, a fact found in literature by Miranda et $\mathrm{al}^{30}$, who observed a considerable reduction in performance in a resistance training session using a 1-minute interval compared to 3-minute interval. For the authors, longer rest intervals between sets and exercises may provide higher stimulus of total repetitions performed with a given load and, consequently, higher training volume. This reduction found in the volume of repetitions in this study may be associated with the shorter proposed two-minute rest interval between sets, which was probably not sufficient for complete recovery of energy systems.

The present study had limitations because it did not evaluate the neuromuscular responses of the investigated stimuli through the use of instruments such as electromyography. The flexibility levels of individuals participating in the sample were not previously measured. In addition, another limitation was the reduced sample size, since larger sample could have obtained different results.

Moreover, this study is relevant because the mechanisms responsible for the increase of strength through the stretching of antagonist muscles verified in previous studies are not clear ${ }^{3,4,16,19,20}$, and even though no significant difference was found between PT and PAA protocols, no decrease in strength performance was observed, and the potential effects of SS through an equipment commonly found in training centers and gyms (leg extension machine) were evaluated in this study, which enables the reproducibility of protocols used in the present study. Further studies should use different stretching protocols and antagonist pre-activation, application of protocols used in different muscles, use of larger samples and use of equipment to evaluate neuromuscular responses. 


\section{CONCLUSION}

Given the above, the results of the present study did not show significant improvement in the maximal repetition performance of agonists by applying static stretching to antagonists in the leg extension exercise. However, there was no decrease in strength performance. As studies in the range of repetitions investigated in this study were not found in literature, it is likely that SS does not influence the performance of maximum repetitions when applied in the range of repetitions focused on muscular endurance. These results suggest that during the elaboration of a strength training program, SS would not be an alternative aiming to improve muscle performance in maximum repetitions. Future studies should investigate the neural and morphological mechanisms that influence this relationship.

\section{COMPLIANCE WITH ETHICAL STANDARDS}

\section{Funding}

This research did not receive any specific grant from funding agencies in the public, commercial, or non-profit sectors. This study was funded by the authors.

\section{Ethical approval}

Ethical approval was obtained from the local Human Research Ethics Committee - Universidade Federal do Rio de Janeiro - UFRJ and the protocol (no. 08657113.0.0000.5257) was written in accordance with standards set by the Declaration of Helsinki.

\section{Conflict of interest statement}

The authors have no conflict of interests to declare.

\section{Author Contributions}

Conceived and designed the experiments: Souza PA, Teixeira DR, Miranda HL, Paz GA. Performed the experiments: Souza PA, Teixeira DR. Analyzed data: Batista CAS. Contributed with reagents/materials/analysis tools: Souza PA, Teixeira DR, Della Corte J, Batista CAS, Miranda HL, Paz GA. Wrote the paper: Souza PA, Teixeira DR, Della Corte J, Batista CAS, Miranda HL, Paz GA.

\section{REFERENCES}

1. Costa PB, Graves BS, Whitehurst M, Jacobs PL. The acute effects of different durations of static stretching on dynamic balance performance. J Strength Cond Res 2009;23(1):141-7.

2. Coelho LFS. O treino da flexibilidade muscular e o aumento da amplitude de movimento: uma revisão crítica da literatura. Motri 2008;4(3):61-72.

3. Paz GA, Leite T, Maia MF, Lima AF, Coelho PP, Simão R, Miranda H. Influência do intervalo de recuperação entre alongamento e treinamento de força. ConScientiae Saúde 2013;12(3):362-70. 
4. Sandberg JB, Wagner DR, Willardson JM, Smith GA. Acute effects of antagonist stretching on jump height, torque, and electromyography of agonist musculature. J Strength Cond Res 2012;26(5):1249-56.

5. Sharman MJ, Cresswell AG, Riek S. Proprioceptive neuromuscular facilitation stretching: mechanisms and clinical implications. Sports Med 2006;36(11):929-39.

6. Murphy JC, Nagle EF, Robertson JR, McCrory JL. Effect of Single Set Dynamic and Static Stretching Exercise on Jump Height in College Age Recreational Athletes. Int J Exerc Sci 2010;3(4):214-24.

7. Rodríguez FA, Andújar PSB. Efecto agudo del estiramiento sobre el sprint en jugadores de fútbol de división de honor juvenil. Rev Int Cienc Deporte 2010;6(18):1-12.

8. Grego Neto A, Manfra EF. Influência do volume de alongamento estático dos músculos isquiotibiais nas variavéis isocinéticas. Rev Bras Med Esporte 2009;15(2):104-9.

9. Amiri-Khorasani M, Sahebozamani M, Tabrizi KG, Yusof AB. Acute effect of different stretching methods on Illinois agility test in soccer players. J Strength Cond Res 2010;24(10):2698-704.

10. Babault N, Kouassi BY, Desbrosses K. Acute effects of 15 min static or contractrelax stretching modalities on plantar flexors neuromuscular properties. J Sci Med Sport 2010;13(2):247-52.

11. Siatras TA, Mittas VP, Mameletzi DN, Vamvakoudis EA. The duration of the inhibitory effects with static stretching on quadriceps peak torque production. J Strength Cond Res 2008;22(1):40-6.

12. Winke MR, Jones NB, Berger CG, Yates JW. Moderate static stretching and torque production of the knee flexors. J Strength Cond Res 2010;24(3):706-10.

13. Cannavan D, Coleman DR, Blazevich AJ. Lack of effect of moderate-duration static stretching on plantar flexor force production and series compliance. Clin Biomech 2012;27(3):306-12.

14. Behm DG, Button DC, Butt JC. Factors affecting force loss with prolonged stretching. Can J Appl Physiol 2001;26(3):261-72.

15. Franco BL, Signorelli GR, Trajano GS, de Oliveira CG. Acute effects of different stretching exercises on muscular endurance. J Strength Cond Res 2008;22(6):1832-7.

16. Gomes TM, Simão R, Marques MC, Costa PB, da Silva Novaes J. Acute effects of two different stretching methods on local muscular endurance performance. J Strength Cond Res 2011;25(3):745-52.

17. Marek SM, Cramer JT, Fincher AL, Massey LL, Dangelmaier SM, Purkayastha $\mathrm{S}$, et al. Acute Effects of Static and Proprioceptive Neuromuscular Facilitation Stretching on Muscle Strength and Power Output. J Athl Train 2005;40(2):94-103.

18. Souza AC, Bentes CM, Salles BF, Reis VM, Alves JV, Miranda H, et al. Influence of Inter-Set Stretching on Strength, Flexibility and Hormonal Adaptations. J Hum Kinet 2013;36:127-35.

19. Miranda H, Paz GA, Antunes H, Maia M, Novaes JS. Efeito agudo do alongamento estático nos antagonistas sobre o teste de repetições máximas para os músculos agonistas. Rev Bras Cienc Mov 2014;22(2):19-26.

20. Miranda H, Maia Mde F, Paz GA, Costa PB. Acute effects of antagonist static stretching in the inter-set rest period on repetition performance and muscle activation. Res Sports Med 2015;23(1):37-50.

21. Robbins DW, Young WB, Behm DG. The effect of an upper-body agonistantagonist resistance training protocol on volume load and efficiency. J Strength Cond Res 2010;24(10):2632-40.

22. Geertsen SS, Lundbye-Jensen J, Nielsen JB. Increased central facilitation of antagonist reciprocal inhibition at the onset of dorsiflexion following explosive strength training. J Appl Physiol 2008;105(3):915-22.

23. Thomas JR, Nelson JK, Silverman SJ, Research methods in physical activity. Champaign: Human Kinetics; 2015. 
24. Thomas JR, Nelson JK, Silverman SJ, Métodos de pesquisa em atividade física. Porto Alegre: Artmed;2012.

25. Paz GA, Robbins DW, de Oliveira CG, Bottaro M, Miranda H. Volume Load and Neuromuscular Fatigue During an Acute Bout of Agonist-Antagonist Paired-Set vs. Traditional-Set Training. J Strength Cond Res 2017;31(10):2777-84.

26. Monteiro WD, Simão R. Existe déficit bilateral na realização de $10 \mathrm{RM}$ em exercícios de braços e pernas?. Rev Bras Med Esporte 2006;12(3):115-18.

27. Wallmann HW, Gillisb CB, Martinez NJ. The Effects of Different Stretching Techniques of the Quadriceps Muscles on Agility Performance in Female Collegiate Soccer Athletes: A Pilot Study. N Am J Sports Phys Ther 2008;3(1):41-7.

28. Gomes FD, Vieira W, Souza LM, Paz GA, Lima VP. Desempenho de repetições máximas após facilitação neuromuscular proprioceptiva aplicada nos músculos agonistas e antagonistas. ConScientiae Saúde 2014;13(2):252-8.

29. Santiago FLS, Paz GA, Maia MF, Santos PS, Santos ATL, Lima VP. Força de repetições máximas e tempo de tensão no leg press pós alongamento estático nos extensores e flexores do joelho. Rev Bras Prescr Fisiol Exerc 2012;6(31):3-9.

30. Miranda H, Simão R, Santos Vigário P, de Salles BF, Pacheco MT, Willardson JM. Exercise order interacts with rest interval during upper-body resistance exercise. J Strength Cond Res 2010;24(6):1573-7.

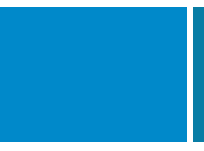

Corresponding author

Camila Aparecida de Souza Batista

Av. Carlos Chagas Filho, 540 - Cidade Universitária, Rio de Janeiro - RJ, Brasil.

E-mail: csbatista87@gmail.com 